ARTICLE

Received 14 Jan 2016 | Accepted 26 Apr 2016 | Published 7 Jun 2016

\title{
Apathy, excitement and resistance: teaching feminism in business and management schools
}

Katherine Sang ${ }^{1}$ and Steven Glasgow ${ }^{1}$

\begin{abstract}
Feminism, gender and women's issues have been side-lined within business and management studies in the United Kingdom, evidenced by the inclusion of only one highly ranked gender journal in the recent ABS journal quality list. While there have been some efforts to critique gendered research norms within business and management schools, less is known about the experiences of those engaged in designing and delivering curricula. This article begins by examining the extant literature on the experiences of feminist academics, leading to a discussion of the limited research on business and management schools. It then moves to a description of the methods adopted, namely, qualitative interviews with academics engaged in feminist teaching, and reflections from the authoring team. The findings are presented, highlighting how participants conceptualize feminism, the use of feminism in curricula development, and how the academic community responds to the teaching of feminism. The article concludes with a consideration of areas for future research. The study contributes to the understanding of the experiences of working within the contemporary business school, specifically for academics engaged in a social justice approach to teaching. It identifies that experiences are not universal, with feminism creating space for excitement for both staff and students, but potentially increasingly vulnerability for isolation and marginalization. This article is published as part of a thematic collection on gender studies.
\end{abstract}

\footnotetext{
${ }^{1}$ Business Management, Heriot Watt University, Edinburgh, UK
} 


\section{Feminist academics}

he use of feminist theory has been key to understanding the persistence of gender inequality (Mirchandani, 2003). Feminist theory has been subject to considerable examination and critique within the academy. In particular, recent critiques have drawn attention to the persistent domination of white Western feminism, and the consequences for the maintenance of racism and colonialism in theorising women's lives (Bhattacharya, 2015; Jonsson, 2016). However, the experiences of those engaged in feminist research and teaching (academic feminists) or those academics engaged in feminist activism (feminist academics) remains relatively scarce. Feminist academics and academic feminists have significantly impacted the academy, rendering visible the biases within knowledge production, and the limitations of claims of objectivity (Skeggs, 2008; David, 2014). Further, feminist research has achieved success in revealing the gendered working conditions of women (and men) academics, and the resulting impact on gender (in)equality (Hart, 2005; Barg, 2009; Parsons and Priola, 2013). However, there is evidence that such academic activism does have risks. Many feminist academics report a "Chilly Climate" (Chilly Collective, 1995; Dixon, 2013), while Davidson and Langan (2006) have suggested that feminist academics are subject to violence. There is some evidence of resistance to feminism from the student body in universities, both in the United Kingdom (for example, Morrison et al., 2005) and internationally (Webber, 2005). Teaching feminism may be more problematic in increasingly managerial and metric driven higher education contexts (Knights and Clarke, 2013). Those engaged in critical education, particular feminist curricula development and delivery, may be more vulnerable to increasing tensions between staff and the student body (Lee, 2005). These effects are not uniform between men and women, with the former often receiving more positive teaching evaluations when delivering feminist curricula (Flood, 2011). Moss and Pryke (2007) have suggested that feminist academics may feel greater pressure than other academics to maintain high levels of student support, for example, pastoral care, while attempting to achieve excellent research. Moss and Richter (2011) have suggested that changes to university funding and the pressure to increase student numbers may reduce the scopeacademics have for working with students to challenge gendered norms.

Feminist ideals may be contra to the requirements of contemporary academic careers (Deem, 2002). Feminist academics in leadership or management positions may find their ideals are in conflict with the division of labour and the politics of knowledge production (Mauthner and Edwards, 2010), although the increased use of metrics may reduce gender bias and enhance women's career opportunities (Deem, 2003). However, as Mauthner and Edwards (2010) articulate, the structure of universities reinforces inequality, for example, so-called junior researchers allocated the underappreciated dirty work of research such as data collection. Senior feminist academic women report having to carry a dual identity whereby they leave their feminist identity at home (Edwards, 2000). Mauthner and Edwards (2010) take these concerns further and suggest that a feminist approach to academic management, for instance, a non-hierarchical approach to team management may be seen as "soft" and be exploited by team members.

The increased emphasis on individualization and metrics inherent in academic careers may be at odds with the collective ethos emphasized by many feminists (Reay, 2000; Skelton, 2004). Any conflict between being an academic and being a feminist predates contemporary changes in higher education. Feminists have challenged the objectivity which is traditionally valued within academia and feminist research typically places greater value on personalized knowledge (Coates et al., 1998; Haynes,
2008). For those feminist academics who research marginalized communities, this work may be hard to publish in leading journals, resulting in a professional cost (Coates et al., 1998; Edwards, 2000). Ketcham Weber et al. (2008) argue the de-valuing of practice has resulted in a focus on feminist theory rather than feminist practice within the Academy, as a result there is comparatively poor understanding of what feminists do here. More optimistically, there have been recent efforts to reveal the potential for feminism within the Academy. Wanggren and Sellberg (2012) identified the classroom is one of the areas where feminists can have the most impact.

The business school context. Much of the extant research on the experiences of feminist academics has been conducted within humanities contexts. The contemporary business school is somewhat different with its focus on producing knowledge and graduates which are ready for the business world (Paton et al., 2014). This is reflected in recent efforts to understand the usefulness of management education, where usefulness is equated to congruence between the teaching of management theory and the practice of managers (Wright et al., 2013). This usefulness may be determined by senior business practitioners (Muff, 2012).

There is a growing body of research on academic labour within business and management schools (for example, Petriglieri and Petriglieri, 2010). UK business and management schools appear, at least numerically, to have relative gender parity in comparison with STEM subjects (Parsons and Priola, 2013). However as Fotaki (2011) articulates, business schools are still dominated by a masculine hegemony. Further, business schools are subject to the increased managerialism outlined earlier, with those who resist or question such changes positioned as problematic or resistant (Parker, 2014). UK business school academics are also operating within a unique context, where a journal quality list, the ABS list produced by the Association of Business Schools (ABS, 2015), is dominant. The impact of journal quality lists and the ABS list, have been subject to considerable critique within business and management research. Although beyond the scope of the current article's focus on teaching, it is worth noting that the ABS list has been critiqued for constraining what constitutes valid knowledge within business schools and discriminating against novel and innovative areas of research (Tourish and Willmott, 2015).

Women academics working in business schools face a range of difficulties. Fotaki $(2011,2013)$ has used feminist poststructuralist and psychoanalytical theory to understand the embodied experiences of women academics in UK business and management schools, the research suggesting knowledge production within the discipline is both heteronormative and phallocentric, while simultaneously presenting a myth of objectivity. Further, Sang et al. (2013) pointed to a range of gendered treatment experienced by women professors, although the migrant women professors were able to progress quickly in the business school.

Harney (2007) called for feminism, particular socialist feminism, to be incorporated into the management curriculum as a route to subverting traditional capitalist concerns of management education. Further, the teaching materials used by business management academics may construct a gendered typical/ideal worker, which creates and reinforces both gender and associated inequalities (Kelan, 2008). However, Ford et al. (2010) have suggested that critical feminist theory can be incorporated into the management curricula, providing students with the opportunity to develop a deep theoretical understanding of their management practice. Despite critiques of feminism and gender within the business curriculum, the experiences of those engaged in teaching feminism, or using feminist texts, remains absent in the literature. This article aims to address this gap, to reveal the 
experiences of women and men engaged in the teaching of feminism in business and management schools.

\section{Methods}

The article draws on the extant literature, a small number of exploratory interviews (email, Skype and face to face), a structured open-ended online questionnaire, personal communications with colleagues and our own reflections as feminist academics within a management school. We make no claims of generalizability, rather this article aims to understand the lived experiences of women and men engaged in teaching feminism within business schools. We were guided by Haynes' (2008) call for greater use of feminist research within accounting (allied to business management), specifically to value the range of subjectivities experienced by women (and men), rather than seeking to identify any particular truth. As such, the current article values the range of subjective experiences of women and men working within the business management school context.

Participants were recruited through the lead author's contacts and a call for participants was also distributed through social media (Twitter and Facebook).). As such, this represents a convenience sample. The call for participants asked for business or management school teaching staff who use feminism or feminist material in their teaching. Given previous work which has suggested gender affects experiences of teaching feminist materials (Stanovsky, 1997) both those who identify as men and women were interviewed.

Interviews were semi-structured allowing for emergingemerging themes to be explored. Questions covered teaching and research expertise, defining feminism, use of feminism in teaching, and responses from students, colleagues and managers. Questions were drawn from the extant literature which suggests that being a feminist academic or engaging with feminist research and teaching, can result in tensions withinwithin working relationships with students and colleagues. An online open-ended questionnaire covering the same matters as the semi-structured was used for the four people who preferred.

The study is also informed by reflections of our own experiences of using feminist material within business schools, in these instances, we adopt the device recommended by Woodward and Woodward (2012) of I-Authorname, in this case I-Kate and I-Steven. The adoption of a self-reflexive approach to our teaching is recommended by Coia and Taylor (2009) as useful for providing insights into our own practice. A similar self-reflective approach has been productively used to reveal the day to day working conditions within the contemporary business school (Parker, 2014). Both I-Kate and I-Steven are located within a management school and identify as feminists. I-Kate is engaged in the design and delivery of an undergraduate module which uses feminist theory. I-Steven was previously a student on I-Kate's module and is currently engaged in $\mathrm{PhD}$ research using feminist theory, while also teaching undergraduate business management modules. All data were subjected to template analysis (King, 2004) which allows for the interview schedule to frame analysis, while retaining flexibility for the incorporation of emerging themes. Initial data coding was undertaken by the lead author, and was verified by the second author.

The current study received full ethical approval from the authors' institution and all participants agreed for their anonymised responses to be used in this article. Identifying as feminists, we also moved beyond institutional ethical research guidelines and drew from feminist ethical principles. Theoretically, there is no consensus on what constitutes as feminist research ethics, much like in the diversity of feminism itself. Debating ethical standpoints is beyond the scope of this article, but we take guidance from Edwards and Mauthner (2002) who emphasize an ethics of care for participants rather than abstract values. In our practice, this included informed consent in the interview being gained through prior conversation to ensure understanding, and pseudonyms being pseudonyms used to protect the identities of participants and their employing institutions.

Participant profile. Table 1.

\section{Findings}

The findings presented here are drawn from the interview data (Skype, face to face, email) and the open-ended questionnaire. The key themes covered here are defining feminism, curriculum development, interactions with students, interactions with colleagues and the perceived impact on career progression.

Defining feminism. For most of the respondents, feminism was a drive for gender equality and a recognition of political, economic, physical and cultural oppression of women. However, a number of respondents felt that feminism's social justice agenda should encompass other social identities:

"It also means struggling against heteronormative constraints that are harmful for both women and men. It also means intersectionality and solidarity, working to include the voices and

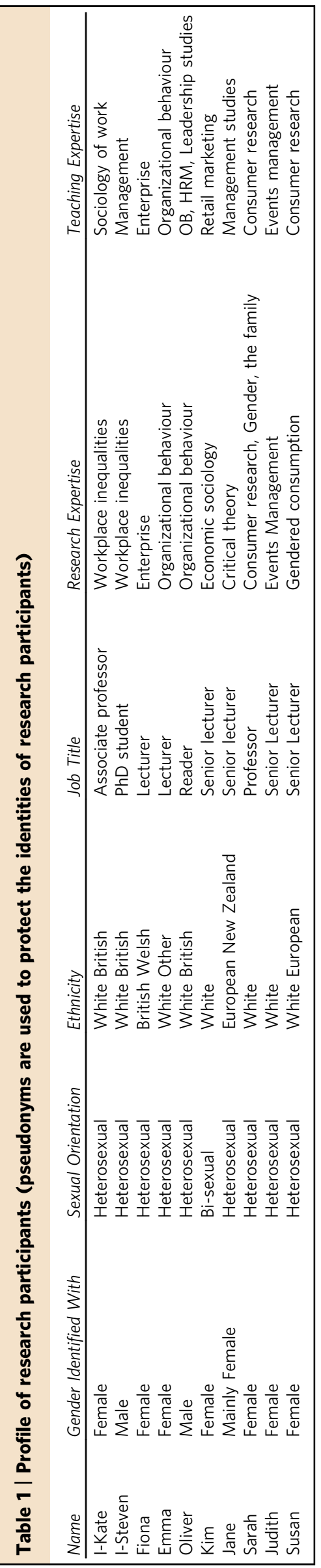


perspectives of women of colour, and women from different class backgrounds, making a common cause with gender-queer folks. It means recognizing difference, trying to understand the consequences differences have for people's life chances, and then trying to do something about it". (Kim, SL, Marketing)

Another participant felt that feminism should also include environmental concerns.

"Feminism means to speak about and for women, and have a concern for the wellbeing of women, others and the planet more generally" (Jane, SL, NZ).

It was clear across the participants that feminism was not solely a political position or identity-rather it was performative, and should be "done", rather than just "said".

Both authors and most of the respondents identified as feminists and as such were both academic feminists, engaged in feminist teaching and research, and also feminist academics, committed to social justice. However, Oliver (Male, Reader, UK) did not:

"I don't identify as a feminist, because I think only women can take the label as an identity-I think men can do feminist things or behave in a feminist way, but not 'be feminist' ".

For Oliver, identifying as a feminist is linked to gender identity, although those who identify as men are able to undertake the performative aspects of feminism.

It was apparent that for participants, feminism has no fixed meaning. Rather it is a diverse concept, although all participants articulated feminism as something which is done, or performative, rather than a theoretical position.

Curriculum development. The data reveal that feminism is often used specifically to teach diversity management, although some respondents indicated that they embed feminism into all of their teaching.

"It's important and necessary for a holistic education. I can't see how I could teach my subject effectively without it" (Judith, SL, UK).

Jane, a New Zealand-based marketing academic, incorporated feminism into her mainstream marketing module to inform student decision making once in the workplace. Specifically, that engaging with feminist material supports the development of students' critical thinking skills:

"Gendering of the marketplace is a common practice and our teaching aim for this paper is to engender a critical awareness of the cultural context of marketplaces in our students. Thus when they are marketing managers they are able to apply a critical perspective to their strategic decisions".

As Jane commented, feminist curricula may be tolerated if they operate discretely or if managers have little interest in day to day managing. Where managers do express interest in curricula development, it can result in depoliticising of courses:

"I would say supportive but they're not invested in my day to day life thank god. I appreciate that they trust me to do what I think is best. It is when managers actually start to manage that I get worried because then they do take an interest in curriculum and start to try and control it. The pressures then become institutional and courses like mine, which is on diversity issues at work, get dumped because the topic can apparently get taught in more 'core' courses. What this means in effect is that they get taught ini a very bland and shallow way with any isms being avoided because the staff teaching these courses have no real familiarity or resonance with the issues".

Jane's quote illustrates a perspective that social justice is considered marginal within business management curricula, and does not warrant specialist course content in its own right. To preserve feminist curricula it may be incorporated by stealth.

One aspect which came across all the various narratives was the lack of readily available course material for feminist courses.
Rather than using a set textbook, respondents and the lead author (I-Kate) use a range of materials, often from outside the management discipline. A further theme which emerged was the need for an online resource which brings together these various feminists texts to aid other feminist academics in their curricula development. The lack of existing textbooks in the area of management theory and business and management studies may be further evidence of the marginalization of feminist theorising. This was further emphasized in communications with participants following the formal data collection. Interest was expressed in establishing an online resource for sharing feminist teaching materials including reading lists and syllabi.

Interactions with students. Although the extant research suggests that feminist academic women may face difficulties in their relationships with students, the current study suggests students express excitement at engaging with feminist materials. I-Kate has experienced only positive feedback from students. Formal feedback through the National Student Survey and institutional surveys has commented on the importance of teaching feminism, and students have appreciated the opportunity to engage with challenging material. Informally, students have said to I-Kate that are fascinated by the topic and enjoy the opportunity to learn about social inequality and have shared their learning with friends, parents and partners. This has applied for both male and female students across a range of disciplines who are undertaking a feminist theory management module. This was echoed by a survey respondent (Susan, SL, UK):

"Every year since I started teaching this topic in the course, I receive several unsolicited emails saying this is the best paper they have experienced in this course/in marketing/in their university career".

These reflections were also evident across other narratives.

"For the most part, they [students] respond really well to it and want to know more about feminist viewpoints and how they can learn more. It's often the first time they come across feminist concepts and ideas, and I think (hope!) it changes their way of viewing the world and thinking about things" (Judith, SL, UK).

The comment below reflects some limited experiences of cultural clashes in the classroom for feminist academics:

"They are challenged and sit up and take notice. I have the odd person who dislikes some of it. I can think of one in particular who was very religious and found the challenge to stereotyped gender roles very tough. Otherwise students take to it like a duck to water" (Jane, SL, NZ).

Oliver's experiences were somewhat different with a perception that male students feel uncomfortable with discussions of feminism and gender inequality. He also felt that the political and cultural context in the United Kingdom is changing and that students are less likely to claim gender equality has been achieved:

"I think reactions are changing, though-last year in particular there was much less claiming that women have achieved equality and so any remaining lacks or inequalities are a result of choice, and much more sense that 'something should be done' [i.e. structural change]. Some men also seem to be more open to feminism as an approach".

I-Steven was first introduced to feminism in I-Kate's taught course. There was an initial awkwardness by male students when confronted by privilege that was previously unaware to them. However, as the evidence of inequality was presented, the importance of feminism was clear. For I-Steven feminism can be a misunderstood concept before the classroom.

Fiona (Lecturer, UK) felt that students have negative connotations of feminism before taking her course. For many students, either equality had been achieved and so feminism was 
"redundant", or saw it as an exclusive practice of "men bashing". Beyond this initial response, as the course progressed and concepts were discussed, these students became more engaged with the material.

Kim (SL, UK) felt that students were resistant to any material which was not seen as directly related to the business curricula, recalling one example of male student who she felt questioned the course relevance and her legitimacy in the classroom:

"Last year, however, I also had one student on the module who was very aggressive about not wanting to read 'non business' material. He was querulous, routinely spoke over me in seminars, interrupted and was quite confident that I was the wrong person to run the module. Eventually he stopped coming to seminars and lectures".

While I-Kate's experiences have been largely positive, there have been examples of postgraduate taught students on Masters of Business Administration and Doctor of Business Administration programmes arguing with some vigour that feminist perspectives are biased research and have no relevance or place in the workplace. I-Kate's reflections suggest these perspectives are rooted in ideologies of positivist research as legitimate research, and demands for profit driven business cases for gender equality. Both I-Kate's and Kim's experience reflect beliefs among some students that social justice, particularly gender equality, is peripheral to learning management and business studies. These concerns are reflective of Jane's comments that if her managers became more aware of what she taught, it might be removed as a specialist subject.

Further, Jane, Professor of Marketing (UK) indicated that for most students, feminist materials in the curricula are seen as a reflection of her own bias and political motivations:

Question: "How would you characterise students' responses to the feminist material you teach?"

Answer: "Either enthusiastic buy in (minority) or mild disdain (majority) often seen as banging my own personal drum".

Interactions with colleagues and managers. Generally respondents felt that teaching feminism did not affect their relationships with colleagues, although this was in part because of apathy and not discussing teaching. Specifically, most respondents reported their colleagues had little interest in what they taught.

Emma (Lecturer, UK) gave a mixed response, which suggests feminist approaches may be undervalued by colleagues:

"I think my research director think it's [feminist teaching] quite cute, he doesn't seem to take it seriously at all, but he's supportive".

Kim (SL, UK) felt that colleagues were resistant to feminism and gender equality measures more generally and this caused tensions in working relationships:

"Mercifully I am not seated amongst people who teach in the same cluster. By some accident, I'm in a different office on another floor. This is a very beneficial arrangement as several of the people in the cluster are very belligerent. One of them claimed, in a recent group meeting, that white men are underrepresented in universities, especially in business schools, so I should stop talking about any need to be inclusive and diverse".

Kim's quote suggests that difficulties have emerged in working relationships when she has attempted to "do" feminism rather than teaching feminism. Kim went on to explain that teaching feminism had resulted in difficulties specifically with male colleagues, but also that there was little solidarity among women colleagues, despite regularly experiencing gender discrimination:

"I don't think it has done me any favours with colleagues. Two male colleagues make a point of trying to wind me up every time I attend a meeting, making needling comments. Silencing techniques are also routinely used in group discussions against women in my cluster, but there is little solidarity or recognition of what is happening. It is a depressing place to be".

Overall respondents felt that managers had little interest in their feminist teaching or research. I-Kate was in a perhaps unusual position of being asked to develop a module on feminist theory, as the then Head of Department felt that this was lacking in the curriculum. Although most academic colleagues have expressed little interest in the feminist curricula, I-Kate has experienced professional services staff expressing a desire to observe her teaching. In addition, male colleagues have requested to attend her lectures and have participated by undertaking the preparatory reading and participating in class discussions.

Career experiences. Participants reported a range of perceived impacts on their career development, as a result of engaging with and teaching feminism.

Kim reflects on the satisfaction she experiences by observing students' response to her teaching.

"It has been more rewarding for me as an academic to watch students develop more critical approaches to gender, and in particular start thinking about how patriarchal social structures and norms have shaped their own experiences-and how they see other people".

I-Kate would echo this experience, gaining considerable satisfaction from observing students challenging their beliefs about gender, and other social identities. Graduated students have maintained contact and reflected on how the critical thinking skills developed through engaging with feminism have been useful in their working and non-working lives.

I-Steven, experienced as both a student and a teacher of feminist material, believes the critical skills that can be delivered through feminism are key contributors for starting his career in academia. Although unsure what affect, positive or negative, this will have on future career progression.

Oliver felt that while engaging with feminist material had opened space for a range of teaching and research interests, it had also resulted in discomfort with the university system and gendered working practices. Specifically, Oliver felt that his intellectual engagement with feminism had resulted in feeling complicit with sexist working practices:

"There's also a quite profound sense of discomfort being involved in [e.g.] selection processes that are sexist, openly or implicitly. For me, there are issues in simply being in the room when this kind of stuff happens, but also in being complicit simply by being part of a patriarchal hierarchy. I suppose you could summarise by saying it's made me much more aware, and quite a bit unhappier".

Respondents did not reflect on the broader climate of higher education, in particular the increased individualization within the context of the neoliberal university. I-Kate, in addition to her feminist teaching and research, is engaged within feminist activism within the academy. As a trade union official and engagement with feminist women's networks, I-Kate is aware of the apathy among staff and students when possibilities for collective action are raised. Efforts with students to question the capitalist project and pursuit of profit through business case arguments for equality are often met with surprise.

One Professor felt that teaching feminism and being a feminist had not adversely affected her career, although she felt that this was an uncommon experience:

"At present I don't think so personally but this may be because I only include it as a facet of teaching-so rather than infuse my teaching with it I include one or two sessions within a 
broader module. I think this is uncommon though" (Sarah, Professor, UK).

\section{Discussion}

The data presented here has revealed a range of experiences and perspectives on feminism and its impact on teaching experiences. There was some evidence of both rewarding and negative experiences within the business and management school context.

For respondents, feminism was performative rather than an identity. This perhaps explains why respondents viewed feminist texts and theoretical perspectives as key to their teaching. As such, this study is supported by Wånggren and Sellberg (2012) who argued that the classroom represents a space where feminism can have impact.

Similarly to previous research (Coates et al., 1998; Morrison et al., 2005) there was some evidence of student resistance to the perceived lack of objectivity in feminist teaching material. This resistance seems to be focussed around two themes. First the perceived bias on behalf of the lecturer, and second, the relevance to the business management curriculum. As Lee (2005) has suggested, there are increasing tensions between staff and the student body. This is in the context of increased focus on graduate employability, even within feminist academic contexts (Moss and Richter, 2011). The data presented here suggests some students share these concerns and question the relevance of feminism and feminist perspectives to their employability within the business world. These perspectives may be linked to demands for a business case for gender equality and a hostility to nonpositivist approaches to research. Although numbers on the current study are small, it is worthwhile to note that men teaching feminism did not report similar criticisms from students. Stanovsky (1997) echoes these limited findings, suggesting that the experience of teaching feminism as a mana can be complicated. However, Flood (2011) points to evidence that male academics delivering feminist curricula receive more positive teaching evaluations from students. The research in this area is limited, and suggests need for further work to understand how gender affects teaching evaluations in the context of feminist teaching and business schools.

In contrast, a number of participants recalled examples of excitement from students when reflecting on feminist teaching. These responses reflected on the opportunity for students' intellectual curiosity to be engaged through teaching feminism. This suggests that the dominant negative discourse within the literature tells a partial story of teaching feminism. Although there are a number of difficulties experienced by feminist academics, particularly within business and management schools, teaching may provide an opportunity for a transformative experience, for both academics and students. The excitement was shared by both academics and students.

That many respondents reflected on the lack of readily available feminist teaching materials for business and management programmes is an area worthy of further consideration. The request from a number of respondents for the research team to set up a freely available online repository of materials and syllabi suggests not only a need for such materials, but for a potential longer term impact of this study. It suggests a sense of isolation amongst some business school academics engaged in feminist teaching. This was supported by respondents' reflections of apathy and little discussion between colleagues, and a perceived lack of solidarity amongst women. It is important to note that this perceived isolation may have motivated participation in the current study. However, future research should consider the avenues for overcoming this isolation and creating space for feminist solidarity between colleagues, both within and between institutions. The increased managerialism in universities has been associated with increased individualization, and is of particular concern to women academics engaged in social justice research (Skelton, 2004). The current study suggests that associated feelings of isolation may extend to teaching.

Given the exploratory research design, it is important to reflect on the effect this has on the usefulness of the data. The use of emailed interviews and open ended online questionnaires provided the opportunity to access the experiences of a dispersed sample, and is particularly useful for researching a sensitive topic. However, it may have limited the fullness of answers and may have excluded academics who prefer not to communicate electronically (James and Busher, 2009). The use of multiple sources of data, face-to-face, email interviews and correspondence, questionnaire and our own reflections helps to overcome these limitations, however, it is difficult to know the extent to which it has shaped the data. Future research may wish to consider alternative research designs as a means to understanding the experiences of academics engaged in feminist curricula design and delivery. However, any alternative approaches must be sensitive to participants' desire to preserve anonymity which was of concern in the current study.

The convenience sampling approach resulted in a sample which was limited not only in size, but also in terms of race and ethnicity. It is possible that the generally positive experiences reported by respondents are linked to forms of white privilege. Further work is required to understand how gender and race intersect to inform the experiences of academics engaged in feminist curricula development and delivery. Given recent critiques of the persistent white domination of the feminist curricula (Bhattacharya, 2015; Jonsson, 2016) further work is required to understand efforts to decolonize the management curricula (Özkazanç-Pan, 2008). The self-reflective approach adopted in the current study has been used to examine the experiences of feminist academics (Woodward and Woodward, 2012) and the changing working conditions in the contemporary business school (Parker, 2014). The current study suggests such an approach can create space for authors to reflect on their own experiences and how this may affect interpretation of the data. Gay and Kirkland (2003) have suggested that such self-reflection is key to all pedagogical practice, but particularly key for those engaged in social justice research. Further longitudinal research may help to reveal how participating in a study which asks academics to reflect on their pedagogical practice, informs future practice.

Overall, this exploratory study has revealed a range of experiences for academics engaged with feminist curricula delivery within the contemporary business school. Experiences are mixed, with feminism offering opportunities to engage in transformational experiences with students, while also creating vulnerability to marginalization by colleagues, and dismissal from students.

\section{References}

ABS (2015) Academic Journal Guide, http://charteredabs.org/academic-journalguide-2015/, accessed 3 May 2016.

Barg R (2009) One foot on the dock and one foot in the canoe. How does a feminist academic fit into fire service education? Adult Education Quarterly; 59 (2) 99-117.

Bhattacharya K (2015) The vulnerable academic personal narratives and strategic de/colonizing of academic structures. Qualitative Inquiry, 1077800415615619.

Chilly Collective. (eds) (1995) Breaking Anonymity: The Chilly Climate for Women Faculty. Wilfrid Laurier University Press: Waterloo, ON, Canada.

Coates J, Dodds M and Jensen J (1998) “Isn’t just being here political enough". Feminist action-orientated research as a challenge to graduate women's studies. Feminist Studies; 24 (2): 333-346. 
Coia L and Taylor M (2009) Co/autoethnography: Exploring our teaching selves collaboratively. In: Tidwell D, Heston M and Fitzgerald L (eds). Research Methods for the Self-Study of Practice, Volume 9, Springer Science and Business Media: The Netherlands, pp 3-16.

David ME (2014) Feminism, Gender and Universities: Politics, Passion and Pedagogies. Ashgate Publishing: Farnham.

Davidson D and Langan D (2006) The breastfeeding incident: Teaching and learning through transgression. Studies in Higher Education; 31 (4): 439-452.

Deem R (2002) Talking to manager-academics methodological dilemmas and feminist research strategies. Sociology; 36 (4): 835-855.

Deem R (2003) Gender, organizational cultures and the practices of manageracademics in UK universities. Gender, Work \& Organization; 10 (2): 239-259.

Dixon KM (2013) How to warm the chilly climate, woman-to-woman. Women in Higher Education; 22 (10): 8-9.

Edwards R (2000) Numbers are not enough: On women in higher education and being a feminist academic. In: Tight M (ed) Academic Work and Life, Volume 1, (International Perspectives on Higher Education Research). JAI Press, pp 307-333.

Edwards R and Mauthner M (2002) Ethics and feminist research: Theory and practice. In: Mauthner M, Birch M, Jessop J and Miller T (eds). Ethics in Qualitative Research; Sage: London, pp 14-31.

Flood M (2011) Men as students and teachers of feminist scholarship. Men and Masculinities; 14 (2): 135-154.

Ford J, Harding N and Learmonth M (2010) Who is it that would make business schools more critical? Critical reflections on critical management studies. British Journal of Management; 21 (s1): s71-s81.

Fotaki M (2011) The sublime object of desire (for knowledge): Sexuality at work in business and management schools in England. British Journal of Management; 22 (1): 42-53.

Fotaki M (2013) No woman is like a man (in academia): The masculine symbolic order and the unwanted female body. Organization Studies; 34 (9): 1251-1275.

Gay G and Kirkland K (2003) Developing cultural critical consciousness and selfreflection in preservice teacher education. Theory Into Practice; 42 (3): 181-187.

Harney S (2007) Socialization and the business school. Management Learning; 38 (2): 139-153.

Hart J (2005) Activism among feminist academics: Professionalized activism and activist professionals. Advancing Women in Leadership Online Journal; 18 (1): $381-404$

Haynes K (2008) Moving the gender agenda or stirring chicken's entrails? Where next for feminist methodologies in accounting? Accounting, Auditing \& Accountability Journal; 21 (4): 539-555.

James N and Busher H (2009) Online Interviewing. Sage Publications: London.

Jonsson T (2016) The narrative reproduction of white feminist racism. Feminist Review.

Kelan EK (2008) The discursive construction of gender in contemporary management literature. Journal of Business Ethics; 81 (2): 427-445.

Ketcham Weber J, Costello L, Gross A, Clemens Fox R and Jacobs L (2008) A dialogue on action: Risks and possibilities of feminism in the academy in the 21st century. Thirdspace: A Journal of Feminist Theory \& Culture; 8 (1) accessible at: http://journals.sfu.ca/thirdspace/index.php/journal/article/viewArticle/weber/228.

King N (2004) Using template analysis in the qualitative analysis of text. Essential Guide to Qualitative Methods in Organisational Research. Sage: London.

Knights D and Clarke CA (2013) It's a bittersweet symphony, this life: Fragile academic selves and insecure identities at work. Organization Studies; 35 (3): $335-357$.

Lee D (2005) Students and managers behaving badly: An exploratory analysis of the vulnerability of feminist academics in anti-feminist market driven UK higher education. Women's Studies International Forum; 28 (2): 195-208.

Mauthner NS and Edwards R (2010) Feminist research management in higher education in Britain: Possibilities and practices. Gender, Work and Organization; 17 (5): 481-502.

Mirchandani K (2003) Challenging racial silences in studies of emotion work: Contributions from anti-racist feminist theory. Organization Studies; 24 (5): 721-742.

Morrison Z, Bourke M and Kelley C (2005) "Stop making is such a big issue": Perceptions and experiences of gender inequality by undergraduates at a British University. Women's Studies International Forum; 28 (2): 150-162.
Moss D and Pryke J (2007) Creating space and time for feminist approaches in higher education. In Women's Studies International Forum; 30 (5): 367-379.

Moss D and Richter I (2011) Changing times of feminism and higher education From community to employability. Gender and Education; 23 (2): 137-151.

Muff K (2012) Are business schools doing their job? Journal of Management Development; 31 (7): 648-662.

Özkazanç-Pan B (2008) International management research meets "the rest of the world”. Academy of Management Review; 33 (4): 964-974.

Parker M (2014) University, Ltd: Changing a business school. Organization; 21 (2): 281-292.

Parsons E and Priola V (2013) Agents for change and changed agents: The micropolitics of change and feminism in the academy. Gender, Work \& Organization; 20 (5): 580-598.

Paton S, Chia R and Burt G (2014) Relevance or "relevate"? How university business schools can add value through reflexively learning from strategic partnerships with business. Management Learning; 45 (3): 267-288.

Petriglieri G and Petriglieri JL (2010) Identity workspaces: The case of business schools. Academy of Management Learning \& Education; 9 (1): 44-60.

Reay D (2000) "Dim Dross": Marginalised women both inside and outside the Academy. Women's Studies International Forum; 23 (1): 13-21.

Sang K, Al-Dajani H and Özbilgin M (2013) Frayed careers of migrant female professors in British academia: An intersectional perspective. Gender, Work \& Organization; 20 (2): 158-171.

Skeggs B (2008) The dirty history of feminism and sociology: Or the war of conceptual attrition. The Sociological Review; 56 (4): 670-690.

Skelton C (2004) Gender, career and'individualisation'in the audit university. Research in Education; 72 (1): 87-102.

Stanovsky D (1997) Speaking as, speaking for, and speaking with: The pitfalls and possibilities of men teaching feminism. Feminist Teacher; 11 (1): 10-19.

Tourish D and Willmott H (2015) In defiance of folly: Journal rankings, mindless measures and the ABS Guide. Critical Perspectives on Accounting; 26, 37-46.

Wånggren L and Sellberg K (2012) Intersectionality and dissensus: A negotiation of the feminist classroom. Equality, Diversity and Inclusion: An International Journal; 31 (5/6): 542-555.

Webber M (2005) "Don't be so feminist": Exploring student resistance to feminist approaches in a Canadian university. Women's Studies International Forum; 28 (2-3): 181-194.

Woodward K and Woodward S (2012) Being in the academy: A cross generational conversation. Equality, Diversity and Inclusion: An International Journal $31(5 / 6): 435-451$

Wright RP, Paroutis SE and Blettner DP (2013) How useful are the strategic tools we teach in business schools? Journal of Management Studies; 50 (1): 92-125.

\section{Data availability}

The datasets generated during and/or analysed during the current study are not publicly available as this may compromise the confidentiality of participants, who are readily identifiable from the dataset.

\section{Additional information}

Competing interests: The authors declare no competing financial interests.

Reprints and permission information is available at http://www.palgrave-journals.com/ pal/authors/rights_and_permissions.html

How to cite this article: Sang K and Glasgow S (2016) Apathy, excitement and resistance: teaching feminism in business and management schools. Palgrave Communications. 2:16023 doi: 10.1057/palcomms.2016.23.

This work is licensed under a Creative Commons Attribution 4.0 International License. The images or other third party material in this article are included in the article's Creative Commons license, unless indicated otherwise in the credit line; if the material is not included under the Creative Commons license, users will need to obtain permission from the license holder to reproduce the material. To view a copy of this license, visit http://creativecommons.org/licenses/by/4.0/ 